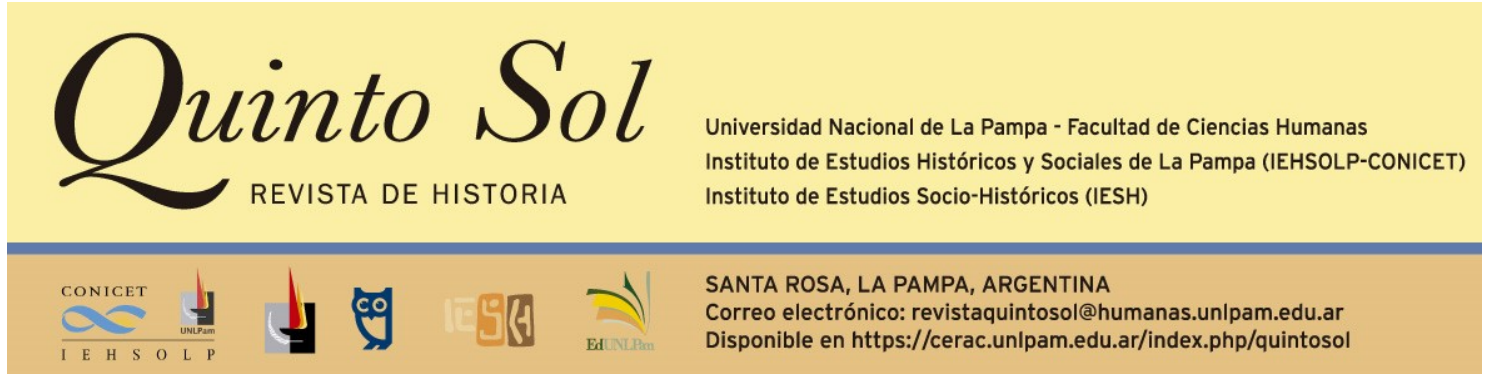

Quinto Sol, vol. 24, n 3, septiembre-diciembre 2020, ISSN 1851-2879, pp. 1-19

DOI: https://doi.org/10.19137/qs.v24i3.4837

Esta obra se publica bajo licencia Creative Commons 4.0 Internacional. (Atribución-No ComercialCompartir lgual)

\title{
Blunting Occam's razor, or when less is not best: pluralism in the global health care marketplace
}

\author{
La navaja de Ockham desafilada, o cuando menos no es más: \\ pluralismo médico en la sociedad global
}

\section{A navalha de Ockham desafiada, ou quando menos não é mais: pluralismo médico na sociedade global}

\author{
Silvia Waisse \\ Tel Aviv University. The Cohn Institute for History and Philosophy of Science and Ideas \\ Israel \\ Pontificia Universidad Católica de São Paulo \\ Brasil \\ Correo electrónico: dr.silvia.waisse@gmail.com
}

\section{Resumen}

Pluralitas non est ponenda sine necessitate. En una curiosa instancia de metábasis, este célebre dicho - "la pluralidad no se debe postular sin necesidad"- parece encontrar contemporáneamente expresión ideal en el área de la salud: el sistema médico derivado de la ciencia moderna occidental se diseminó ampliamente, al punto de ser globalmente conocido como 'medicina convencional'. Esta parece ser también la percepción de diversos investigadores -historiadores, especialistas en medicina social, entre varios otros- que han enfatizado la difusión global de la medicina occidental, citando, como notas al margen, la 'llegada' de otros sistemas médicos considerados 'alternativos' o 'complementarios', en el mejor de los casos. Sin embargo, la integración de diversas tradiciones culturales es un fenómeno que viene ganando

\section{Palabras clave} medicina tradicional medicina convencional integración organización del conocimiento 
espacio y visibilidad. Un ejemplo notable lo representan los esfuerzos para establecer diálogo entre diversas culturas médicas, ya no en relación de subordinación, sino como equivalentes en sus contribuciones al objetivo general de promoción, preservación y recuperación de la salud física, mental y social. El foco de este trabajo es la construcción de un marco conceptual y metodológico unificado como parte de la iniciativa de la Organización Mundial de la Salud para crear un sistema de clasificación que facilite la comprensión de tendencias globales y locales. Como estudio de caso, se analiza la reciente (mayo de 2019) inclusión de la llamada Medicina Tradicional en la $11^{\text {a }}$ edición de la Clasificación Internacional de Enfermedades (CIE11), que entrará en vigor el $1^{\circ}$ de enero de 2022.

\section{Abstract}

Pluralitas non est ponenda sine necessitate -"plurality should not be posed without necessity"- states the famous dictum. In a curious case of metabasis, it seems to apply nowhere best than in contemporary health care: the approach that unfolded as an offshoot of modern science in the West became so pervasive that is now globally known as 'conventional' medicine. This seems to be also the perception of scholars -historians, social medicine experts, among many others- who have stressed the global spread of Western medicine, while allowing for some footnotes on the 'arrival' of other approaches, which nonetheless remain 'alternative' or, in the best of cases, 'complementary' to mainstream health care. Integration of cultural traditions, however, is increasingly gaining territory and visibility. One striking example is provided by endeavors to make the various health care traditions communicate, no longer within a relationship of subordination, but as equally contributing to the general goals of promoting, maintaining and helping recover physical, mental and social health. In this paper I address the effort to create a common conceptual and methodological frame within the World Health Organization (WHO) initiative to develop a classification to enable the involved actors understand global and local trends. My particular focus is on the recent (May 2019) inclusion of Traditional Medicine conditions in the International Statistical Classification of Diseases and Related Health Problems, 11th revisionICD-11, effective starting 1 January 2022

\section{Resumo}

Pluralitas non est ponenda sine necessitate. Em uma curiosa instancia de metábasis, esta célebre frase -"a pluralidade não deve nunca ser posta sem necessidade"- parece encontrar uma expressão ideal contemporaneamente na área da saúde: o sistema medico derivado da ciência moderna ocidental disseminou-se amplamente até ser globalmente conhecida como "medicina convencional". Esta parece ser também a percepção de diversos investigadores -historiadores, especialistas em medicina social, entre outros- que enfatizaram a difusão global da medicina ocidental, citando, como rodapé, a "chegada" de outros sistemas médicos considerados "alternativos" e "complementários". Porém, a integração de diversas tradições culturais

\section{Keywords}

traditional medicine conventional medicine integration knowledge organization

\section{Palavras-chave}

medicina tradicional medicina convencional integração organização do conhecimento 
é um fenômeno que vem ganhando espaço e visibilidade. Um exemplo notável são os esforços para estabelecer diálogo entre diversas culturas medicas, já não em relação com a subordinação senão como equivalentes em suas contribuições ao objetivo geral de promoção, preservação e recuperação da saúde física, mental e social. O foco deste trabalho é a construção de uma estrutura conceitual e metodológica unificada como parte da iniciativa da Organização Mundial da Saúde para criar um sistema de classificação que facilite a compreensão de tendências globais e locais. Como estudo de caso, analisa-se a recente (maio de 2019) inclusão da nomeada Medicina Tradicional na $11^{\circ}$ edição de Classificação Internacional de Enfermidades (CIE-11), a qual entrará em vigência em $1^{\circ}$ de janeiro de 2022.

Recepción del original: 02 de noviembre de 2019.

Aceptado para publicar: 16 de marzo de 2020. 


\section{Blunting Occam's razor, or when less is not best: pluralism in the global health care marketplace}

\section{To be or not to be: classifications as epistemological birth certificates?}

To classify is to introduce methodical order in a dataset to produce knowledge out of information (Souza, 2010, p. 56). It thus comes as no surprise that the interest in organizing knowledge began together with the earliest human attempts at making sense of the world (Alfonso-Goldfarb et al, 2013, p. 552). In a globalized world like ours, in addition to ensuring the consistency of the data, an explicit task of knowledge organization is to make it comparable. This is the role of internationally endorsed classifications (Madden et al, 2007).

Internationally endorsed classifications of health-related subjects began to be developed in 1893 with exclusive focus on causes of death. Over time, also morbidity was included, and after the World Health Organization (WHO) was created in 1948, ${ }^{1}$ it was commissioned to prepare and publish revisions of the International Classification of Diseases and Related Health Problems (ICD). ICD is considered the "foundation for the identification of health trends and statistics globally and the international standard for reporting disease and health conditions," and it provides the "diagnostic classification standard for all clinical and research purposes." ${ }^{2}$

As a result, ICD is used by policy makers and health care managers, and also for billing, epidemiology, research, clinical diagnosis and death certificates. Therefore, upon being included into ICD any condition acquires an internationally recognized identity and is certified as a legitimate epistemic object.

In May 2019, the World Health Assembly adopted the 11th revision of ICD (ICD11) to come into force on 1 January 2022. ICD-11 has several revolutionary features: it is the first version entirely developed on internet-based workspace, it was prepared by 300 specialists from 55 countries, it enables combinations of basic and extension codes resulting in clinically relevant categories and it is based on a new ontology that enables machine or human use. And for the first time ever ICD includes a supplementary chapter for Traditional Medicine (TM) conditions-Module 1: East Asian/Chinese-based Traditional Medicine (TM1). ${ }^{3}$ The latter is quite a remarkable development, given that since 1967 the WHO recommends Member States to use the most current version of ICD for mortality and morbidity statistics (World Health Assembly 20, 1967).

\footnotetext{
${ }^{1}$ For a history of the World Health Organization, with emphasis on geopolitical context and WHO programs, see Cueto, Brown \& Fee (2019).

2 World Health Organization (WHO). Classifications. Available at: https://www.who.int/classifications/icd/en/.

3 WHO. ICD-11 for Mortality and Morbidity Statistics (Version: 04/2019). Available at: https://icd.who.int/browse11/l-m/en.
} 
Shortly, through its inclusion in ICD-11 TM1 acquired internationally endorsed identity, despite the proviso that "the TM1 chapter is not judging TM practice or the efficacy of any TM intervention." ${ }^{4}$

Yet, the scientific community immediately perceived the true implications well beyond the scope of health care. An editorial published in the prestigious journal Nature, a few days after the official announcement by WHO, expresses the new state of affairs in no ambiguous terms: "the WHO chapter on traditional medicine... risks legitimizing an unfounded underlying philosophy." ${ }^{5}$

My intention in this paper is not to discuss the effectiveness/efficacy of traditional and complementary medicine, its history, or the reception of the WHO's decision by the institutions of Western conventional science and medicine. My interest here is in this new chapter of the history of pluralism in the health care marketplace, characterized by the integration of an alien medical system into the conceptual frame of the dominant one. The tip of this iceberg is precisely represented by the inclusion of TM1 in ICD-11.

In the first section of this paper I summarize the terminology used by stakeholders to refer to the various systems of medicine currently in use and their possible patterns of interaction. Next I briefly address the history of present-day Traditional Chinese Medicine (TCM) to introduce a case study -that of the isolation of artemisinin- to illustrate the type of interaction ICD-11, and the wider scoped project of integration from which it derives-seek to promote. As mentioned above, my focus is on classifications as perceptible manifestation of the organization of knowledge, understood as both the result of and as shaping our ways of thinking. Therefore, the third section is devoted to the family of classifications formulated by WHO as the conceptual frame into which, currently two, different medical systems -Western conventional medicine and Traditional Chinese Medicine- are meant to be integrated. As I shall argue, this is not a matter of taste or of privileging TMC over other nonconventional medical traditions, but the result of conscientious and intentional efforts, starting in the mid-1950s, to rework this millenary medical system in the light of contemporary science and technology. This said, in the following section I emphasize the overall perception that traditional medical approaches and other forms of complementary and alternative medicine are not a poor cousin to Western conventional medicine. Much to the contrary, their use has dramatically increased also in Europe and North America, particularly among the population with higher educational level and income. This widespread use of nonconventional medicine called attention to the need for a conceptual categorization to enable global knowledge exchange, education and research. I conclude with a historiographical analysis of the concept of medical pluralism to advance the hypothesis that nonconventional medicine is, in fact, nothing new or 'alternative.' As Roberta Bivins (2007, p. 171) argues "to regard some medical systems, theories and practices as alternative, one must first have

4 WHO. ICD-11 Reference Guide. 1.5 Traditional Medicine. Available at: https://icd.who.int/icd11 refguide/en/index.html\#1.5Traditionalmedicine\%7Ctraditional-medicine\%7Cc1-5.

${ }^{5}$ Editorials. The WHO's decision to include TCM in its global diagnostic compendium could backfire. (2019). Nature, 570, 5 (my emphasis). See also the official statement by the highly influential European Academies' Science Advisory Council (EASAC) and the Federation of European Academies of Medicine (FEAM) published November $2019 . \quad$ Available at: https://easac.eu/fileadmin/PDF_s/reports_statements/Traditional_Chinese_Medicine/EASAC-

FEAM_TCM_statement_final_Nov_2019.pdf. 
a recognized, definable and at least stable orthodoxy." What seems to be new, ultimately, is the claim of just one system in the medical marketplace to be the single one valid and legitimate, the norm against which everything else is categorized as 'alternative.' Therefore, more than a new phenomenon, we are perhaps witnessing a reappearance of plural medical traditions following an eclipse that has not yet run its full course.

\section{What's in a name? The terminological labyrinth}

One may define medical pluralism as the concomitant employment of more than one medical system for health and illness (Shi et al, 2010). As a consensual point of departure, one should bear in mind that not until the mid-1800s that, in the name of 'science', Western university-trained physicians claimed a monopoly on the medical power of interpretation, which took an entire century to grow roots (Jütte, 2017, p.1). ${ }^{6}$

Nevertheless, in no time or place Western conventional medicine's dominance over rival systems was ever absolute (Baer, 2004, p. 111). Furthermore, the notion of medical pluralism has recently gained new currency, on the one hand as a function of the successes attributed to Traditional Chinese Medicine $(T C M)^{7}$ (Leslie, 1980, p. 191) and on the other, due to the growing popularity of alternative medicine, the global public health care funding crisis, and the intensified exchange of people, goods and practices on a global scale (Penkala-Gawęcka \& Rajtar, 2016, p. 129).

Given that different medical systems, or cultures, do coexist in the contemporary global society, the question to answer is: how? The various terms used over time to designate medical systems other than Western conventional medicine may provide a hint. ${ }^{8}$ The most widely known among such terms is 'Complementary and Alternative Medicine' (CAM) which evidently denotes that the systems in question may represent an excluding option to the dominant one, or can be used in an adjuvant manner. The WHO (2013, p. 7) defines CAM as a "broad set of health care practices that are not part of that country's own traditions or conventional medicine and are not integrated into the dominant health system." This immediately leads to a second notion, that of Traditional Medicine, characterized as the "sum total of the knowledge, skill and practices based on the theories, beliefs and experiences indigenous to different cultures, whether explicable or not, used in the maintenance of health as well as in the prevention, diagnosis or treatment of physical or mental illness" (WHO, 2013, p. 7). Also, TM can be used as an alternative or an adjuvant approach. For this reason, in many countries TM is seen as complementary, whence the WHO's designation 'Traditional and Complementary Medicine' (T\&CM).

\footnotetext{
${ }^{6}$ For a more thorough analysis of historical developments and characteristics of medical pluralism, see Jütte (2013); Dinges (2014).

${ }^{7}$ As I discuss later in this paper, according to scholars the term TCM is commonly applied to a "recent reconstruction of diverse medical traditions mainly during the Maoist era. It incorporates ideas drawn from Western medicine and science, discards aspects of tradition that appear unscientific and attempts to create a homogeneous field of theory and practice" (Gross, 2018, p. 336). Therefore, in the present article I used 'TCM' in this sense, while to allude to premodern approaches I had resorted to the term 'Chinese medicine.'

${ }^{8}$ As an additional result of the issues I discuss here, neither the designation of this system is univocal, and not even the WHO has given it a standard name, possibilities including: allopathic medicine, biomedicine, mainstream medicine, orthodox medicine, among many others, none of them free from semantic and epistemological problems.
} 
Yet, there is another mode of coexistence, in which no system is fully alien or a priori subordinated to another, but they become mutually integrated. This perception recently gave rise to a new term, 'Integrative Medicine' which designates "integrative approaches of both T\&CM and conventional medicine regarding policy, knowledge and practice" (WHO, 2019, p. 14). As a result, starting mid-2017 the WHO Traditional and Complementary Medicine unit was renamed Traditional, Complementary and Integrative Medicine (TCl). The inclusion of TM1 in ICD-11 provides an example of how such integration can be achieved.

\section{Gu wei jing yong - a case of success}

The inclusion of East Asian/Chinese-based Traditional Medicine Module (TM Module 1) -or for that matter, of traditional medicine as such- in ICD-11 is no chance or arbitrary affair, but the result of 50 years of committed work. The timeline depicted in Figure 1 represents milestones of this process.

The millenary Chinese Empire ended in 1912, with the establishment of the Republic of China, when the country opened to the West. Yet, already by the end of the previous century Western medicine had begun entering China together with foreign traders, missionaries and Chinese students who had learned Western medicine abroad. ${ }^{9}$ While the two medical systems, zhong yi 中醫 and xi yi 西醫 (Chinese and Western medicine, respectively) succeeded in coexisting somehow, in time the latter came to be privileged and the former dismissed, if not actually despised. In any case, Western medicine was not available to all, but just to a selected few and mainly in big cities. By 1949 , i.e. when the People's Republic of China was established, only a small proportion of the population had access to proper medical care, especially in rural areas.

The solution came during the Cultural Revolution (1966-1976) from the Party calls Gu wei jin yong 古為今用 (Let the past serve the present) and Zhong xi yijie he 中 西醫結合 (Let's integrate Chinese and Western medicine). In few words, to revise and strengthen the concepts, methods and resources of the millenary Chinese medical tradition according to modern scientific standards (Métailié, 2019).

The results were spectacular: in record time the health care manpower improved and Chinese medicine was incorporated into all levels of health care services. ${ }^{10}$ The global effects were no less powerful: health policy makers were thoroughly impressed and the program success strongly influenced the 1978 Declaration of Alma Ata, as is known, a landmark in global public health (Gross, 2018, p. 334). ${ }^{11}$

\footnotetext{
${ }^{9}$ This section is a short summary of data taken from Jingfu (1985); Sivin (2001); Métailié (2015, 2019); Gross (2018). I thank Prof. Dr. Georges Métailié, the author of Science and Civilisation in China, Volume VI, Part 4, for his help in tracing the contours of this complex landscape, which he also had occasion to experience personally during stays in China in 1964/66 and 1978/83, i.e. before and after the Cultural Revolution.

${ }^{10}$ In the late 1940s, there were about 51,000 Western medicine practitioners for a population of about 540 millions (1/10,588); the rate fell to 2.4 providers/1,000 population in 1985; see Jingfu (1985, p. 13); Gross (2018, p. 338).

${ }^{11}$ The Declaration of Alma Ata -a major milestone in public health that asserts the crucial role of primary health care- was adopted at the International Conference on Primary Health Care, held on 6 to 12 September 1978 in Alma Ata, Kazakhstan, hosted by WHO, UNICEF and the government of Kazakhstan. For the origins of primary health care, see Cueto (2004).
} 
Figure 1: Milestones in the path of inclusion of TM1 in ICD-11

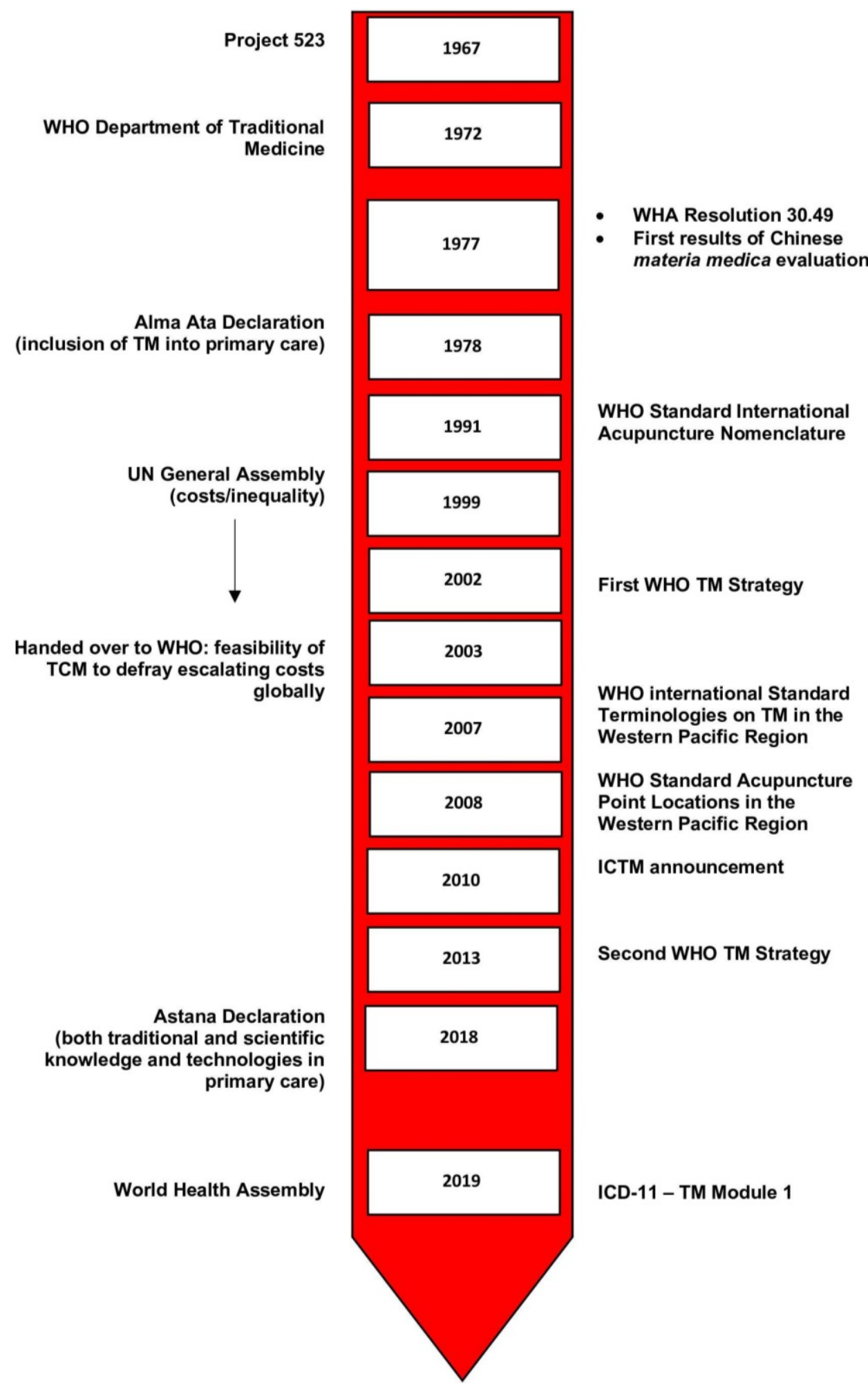

Source: the author

A particularly striking mark of success was achieved when the Nobel Prize in Physiology or Medicine was awarded to Youyou Tu (b. 1930) in 2015. She was the first 
Chinese Nobel laureate in this category, and the first Chinese female laureate ever. ${ }^{12} \mathrm{Tu}$ earned a degree in conventional pharmacology at University of Beijing (1955) to then receive training in Chinese medicine devised for professionals with background in Western medicine (1959-1962) while working as a researcher at the China Academy of Traditional Chinese Medicine (present-day China Academy of Chinese Medical Sciences). In 1969 she was appointed head of a research group within the context of Project 523.

As part of the efforts to recuperate Chinese medicine, a major project, involving more than 500 scientists and about 60 laboratories, was launched in 1967 -Project 523to thoroughly revise the traditional materia medica in the light of modern scientific methods. The earliest results began to be published 10 years later-Quan guo zhong caoyao huibian 全國中草藥匯編 (Compilation of medicinal plants of the whole country) and Zhongyao da cidian 中藥大辭典 (Great dictionary of Chinese materia medica)(Métailié, 2019).

The project, however, also had a more immediate concern: the considerable mortality by chloroquine-resistant malaria. Tu's group engaged in extracting and isolating constituents with possible antimalarial activity from Chinese herbs. This task demanded reviewing hundreds of traditional sources of materia medica and analyzing more than 2,000 herb preparations until they found a match: artemisinin (qinghaosu 青 蒿素) based on a fourth-century book, Ge Hong's (283-343) Zhou hou jiu zu fang 时后 救卒方 (Handbook of prescriptions for emergencies).

Extremely interesting for my purpose in the present study is the fact that Tu's group had initially used conventional extraction methods, involving heating, which destroyed the active components of qinghao 青蒿 (Artemisia annua L., sweet wormwood). They found the solution in Ge Hong's book, according to which to reduce fevers, one had to soak a handful of qinghao in about one liter of water, strain and drink (Klayman, 1985, p. 1049). This was the breakthrough: by reinterpreting the traditional procedure in modern scientific terms, Tu's group understood that extraction had to be performed in cold (Tu, 2011, p. 1217). Also how the compound was named in Chinese points to paths of integration: qinghao is the Chinese name of sweet wormwood; the name given to the active component, artemisinin, is qinghaosu, where the suffix su denotes 'basic element' (Tu, 2011, p. 2018).

Following Tu's methods, in 1985 David Klayman, from the Walter Reed Army Institute of Research in the United States, succeeded in isolating artemisinin from a local species of Artemisia (Miller \& Su, 2011). Today, artemisinin-based combination therapy $(\mathrm{ACT})$ is the standard treatment for Plasmodium falciparum malaria worldwide. $^{13}$

Yet integration was meant to have a much wider scope: to combine TCM and Western medicine at all levels and thus give rise to a new form of integrative medicine with the best of both systems and offsetting the weaknesses of each, always through the application of the knowledge and methods of modern science and technology to the use and development of the traditional lore (Tong, 1985, p. 34).

The "tremendous success of the Chinese experience in the integration of Western medicine and Chinese traditional medicine" (WHO, 1977, p. 1) led to the World

\footnotetext{
${ }^{12}$ The data supporting the discussion in this section were taken from Tu (2011); Klayman (1985); and Miller \& Su (2011).

${ }^{13}$ WHO. Malaria. Available at: https://www.who.int/malaria/areas/treatment/overview/en/.
} 
Health Assembly Resolution no. 30.49 -"Promotion and development of training and research in traditional medicine"- adopted in May 1977. This is considered the official beginning of WHO's endorsement of TM (Foran, 2007, p. 75) and was followed by a meeting six months later to discuss plans, held in Geneva from 28 November through 2 December (WHO, 1977). An immediate result was the explicit inclusion of TM in primary health care in the Declaration of Alma-Ata, the following year:

Primary care...relies, at local and referral levels, on health workers, including physicians, nurses, midwives, auxiliaries and community workers as applicable, as well as traditional practitioners as needed, suitably trained socially and technically to work as a health team and to respond to the expressed health needs of the community. ${ }^{14}$

All enthusiasm notwithstanding, not too much advance was apparently made for the following 20 years. ${ }^{15}$ The Chinese government kept Project 523 secret: the researchers were not allowed to publish outside China and no one not directly involved in the project was aware of its existence (Tu, 2011, p. 1218; Miller \& Su, 2011). ${ }^{16}$

\section{All in the family: the WHO's Who's Who}

By the end of the past millennium, the United Nations (UN) General Assembly launched a discussion on the rising costs of pharmaceuticals, diagnosis and surgical interventions, particularly among the countries which provided socialized medicine. In 2003, the UN handed over this issue to WHO, with the idea to study the feasibility of using the famously successful TCM to counteract the escalating costs of health care globally (Morris et al., 2012, p. 39). The resulting project had three components:

- Standard acupuncture points-achieved with the publication in 2008 of Standard Acupuncture Point Locations in the Western Pacific Region, to reach a consensus and thus overcome differences in the location of acupuncture points, which hindered research and education in the Western Pacific region, where this medical approach has been practiced for more than 2500 years.

- Standard terminology-completed in 2007, with the publication of WHO International Standard terminologies on Traditional Medicine in the Western Pacific Region

\footnotetext{
${ }^{14}$ Declaration of Alma-Ata. (1978). International Conference on Primary Health Care, Alma-Ata (former) USSR, 6-12 September. Available at: https://www.who.int/publications/almaata_declaration_en.pdf (my emphasis).

${ }^{15}$ Except for the publication of Standard International Acupuncture Nomenclature, in 1991, with the "English translation of the name of each meridian and an alphanumeric code derived from the English names and the Chinese phonetic alphabet (Pinyin) names and the Han character names of the meridians and acupuncture points to facilitate teaching, research and clinical practice of acupuncture, as well as exchange of information globally" (WHO, 1990).

${ }^{16}$ According to $\mathrm{Tu}$ (2001, p. 1218) the first communication of her discovery to the West took place in Beijing, in 1981, during the 4th meeting of the Scientific Working Group on the Chemistry of Malaria, sponsored by the United Nations Development Program, the World Bank, and WHO. Miller \& Su (2011) go much farther and observe that when they had started their study in 2007 (i.e. four years before Tu's paper in Nature, on the occasion she was awarded the Lasker-Debakey Medical Research Award) it was entirely unknown who had actually discovered artemisinin and based on their findings, they were persuaded there was "no doubt that the major credit must go to Youyou Tu."
} 
- And a set of diagnostic codes for TM, the International Classification of Traditional Medicine (ICTM), to enable data collection all around the world and to be included in the WHO Family of International Classifications (WHO-FIC) officially launched in $2001 .^{17}$

WHO-FIC consists of several classifications endorsed by the WHO to describe various aspects of health and health systems in a consistent manner (Madden et al, 2007, p. 5.) In 2006 a proposal was effectively made to include the projected ICTM in the WHO-FIC, for which purpose its structure was to be derived from that of ICD-10, i.e. a Western medicine conceptual and methodological frame, so it could be incorporated into ICD-11. The WHO Western Pacific Regional office thus committed to standardize TM clinical diagnoses through evidence-based approaches until 2010. This project was initially meant to cover TM as practiced in China, Japan, Korea, Viet Nam and Australia. However, it was already conceived of as an international classification that over time would also include TM terms and classes from countries in other regions (Choi et al, 2006). ${ }^{18}$

As was mentioned in the first section of the present paper, inclusion into the core reference classification of the WHO-FIC would rise the status of TM to that of Western conventional medicine, while adoption of evidence-based standards and the ICD-10 frame would represent the true embodiment of integration.

The WHO and the UN reaction could not have been more enthusiastic. On 7 December 2010 both agencies published press releases announcing the launching of the ICTM project, namely, an "evidence base for TM, producing terminologies and classifications for diagnosis and interventions." ${ }^{19}$ In support, these agencies observed that for up to $80 \%$ of the population in several parts of the world (mainly the Western Pacific and Southeast Asia regions, Africa and Latin America) TM represented the main source of health care. At the same time, use of complementary and alternative medicine was on the rise in Europe and North America, especially among the population groups with higher income and educational levels.

\footnotetext{
${ }^{17}$ World Health Organization (WHO). Meeting of Heads of WHO Collaborating Centres for the Family of International Classifications, p. 2. Bethesda, MD, USA, 21-27 October 2001. Available at: https://www.who.int/classifications/network/2001_WHOFICNetworkReport.pdf?ua=1.

${ }^{18}$ WHO-FIC comprises three types of classifications: reference, which cover the main parameters of health and health systems, are the product of international agreements, are broadly accepted, there is official agreement for their use, have been approved and are recommended as guidelines for international reporting, and may be used as models for revisions of other classifications. There are currently two reference classifications, ICD and the International Classification of Functioning, Disability and Health (ICF); derived, based upon one or more reference classifications and are consistent with them, which may be designed to provide additional detail or be prepared through rearrangement or aggregation of items. Examples are: ICD-O-3 (for oncology), ICD-DA (for dentistry and stomatology), ICD-10-NA (for neurology), ICF-CY (for children and youths) and the ICD-10 Classification of Mental and Behavioral Disorders; and related, which cover aspects not considered in the reference or derived classifications; examples are: International Classification of Primary Care (ICPC), International Classification of External Causes of Injuries (ICECI), the ATC classification system (Anatomical Therapeutic Chemical Classification) and ISO 9999 -a classification of assistive products for persons with disabilities-. See Madden et al (2007, pp. 8-9); Organisation Internationale de Normalisation, ISO 9999, available at: https://www.iso.org/standard/60547.html; European Commission, WHO ATC Classification System, available at https://ec.europa.eu/cefdigital/wiki/pages/viewpage.action?pageld $=52609352$.

19 WHO Media Centre, 7 December 2010, available at: whoint/mediacentre/news/notes/2010/trad_med_20101207; UN News, 7 December 2010, available at: news.un.org/en/story/12/361192.
} 


\section{"Not a poor man's alternative to Western medical care"}

In the last instance, one may see this razor-sharp judgment by the WHO as the ultimate rationale underlying the ICTM project. ${ }^{20}$ It represents a formal recognition of the more and more pervading relevance of $\mathrm{TCl}$ for all populations in the contemporary global society.

This was no groundless opinion: since 2002 the WHO is closely monitoring the global situation of $\mathrm{TCl}$. That year, according to Member States reports, $75 \%$ of the French, $70 \%$ of Canadians and almost half the population of Australia (48\%) and the United States (42\%) (WHO, 2002, p. 1) used some form of CAM. In 2009, 67\% of Swiss voters were for a new constitutional article on CAM inclusion in the basic health insurance scheme (WHO, 2013, p. 30), following a long period of exhaustive evaluation (Bornhöft \& Matthiessen, 2011). By $2013 \mathrm{TCl}$ had become available in almost every country in the world, the demands continuously increasing (WHO, 2013, p. 7). Acupuncture, for example, is currently available in about $80 \%$ of countries and $\mathrm{TCl}$ is taught at university level in 30\% (WHO, 2013, p. 23). Globally, 88\% of WHO Member States reported using $\mathrm{TCl}$ in 2019 (WHO, 2019), p. 10) while it is covered by health insurance in about one-fourth, at least partially (WHO, 2019, p. 53).

As per the Declaration of Astana, adopted at the Global Congress on Primary Health Care, in October 2018, both scientific and traditional knowledge are needed to "strengthen PHC [primary health care], improve health outcomes and ensure access for all people to the right care at the right time and at the most appropriate level of care." ${ }^{21}$ The focus of the WHO 13th General Program of Work, which came into effect this year -2019- is to ensure universal health coverage. Within this context, $\mathrm{TCl}$ is expected to make a significant contribution, provided it is included in the essential health services (WHO, 2019, p. 10, my emphasis).

Given this situation, the involved actors came to realize that a standard terminology and classification system was essential to enable global knowledge exchange and facilitate efficient and effective use of $\mathrm{TM}^{22}$ Accordingly, the planned ICTM will include disease terms from the various $\mathrm{TCl}$ systems, organized in four modules, as follows: 1. East Asian/Chinese-based TM, including the variants developed in China, Japan and Korea (CJK), Mongolia and others; 2. Ayurveda, including varieties from India, Sri Lanka, Bangladesh, Nepal and others; 3. Homeopathy, as used in Germany, the United Kingdom, France and others; and 4. Other TM systems with independent diagnostic conditions. ${ }^{23}$ The choice to start with module 1 -and actually the driving force behind the entire project- was the fact that harmonization between Western medicine and TM has been long and strongly promoted in China, Japan and

\footnotetext{
${ }^{20}$ WHO/HIS/CTS 2010/03. Traditional Medicine Health Information Systems. Integrating Traditional Medicine into WHO-FIC, p. 2. Available at: https://sites.google.com/site/whoictm/.

${ }^{21}$ Global Conference on Primary Health Care. Declaration of Astana. Astana, Kazakhstan, 25-26 October 2018. Available at: https://www.who.int/docs/default-source/primary-health/declaration/gcphcdeclaration.pdf.

${ }^{22}$ WHO/HIS/CTS 2010/03. Traditional Medicine Health Information Systems. Integrating Traditional Medicine into WHO-FIC, p. 2.

${ }^{23}$ WHO/HIS/CTS 2010/03. Traditional Medicine Health Information Systems. Integrating Traditional Medicine into WHO-FIC, p. 8.
} 
Korea, which countries in addition were already using TM classifications in health information systems. ${ }^{24}$

\section{Final remarks: from 'revived' to 'eclipsed' alterities}

"I am thinking, brother, of a prediction I read this other day, what should follow these eclipses." William Shakespeare, King Lear, Act 1, Scene 2

"In dim eclipse, disastrous twilight sheds On half the nations, and with fear of change." John Milton, Paradise Lost, Book I, lines 597-8

The invitation to contribute to the present dossier on historical aspects of global health challenges explicitly asked to focus on efforts, debates and proposals related to Western medicalization in the twentieth century and the involved national and supranational institutions. My contribution, however, points somehow to the opposite direction. Therefore I am extremely grateful to the editors, María Silvia Di Liscia and Patricia Palma, for having granted me an opportunity to call the attention to ongoing developments which one may easily lose from sight while the 'eclipse' to which I alluded in the heading of this section has not yet run its course.

For many years now one single narrative seems to have pervaded the space of the discourses on health. According to this narrative, 'alternative medicine' is a new phenomenon or a "topical acknowledgment of postmodern medical diversity" (Kaptchuk \& Eisenberg, 2001, p. 189). Possible causes are many: the failure of Western conventional medicine to deliver on its -inflated-promises, the authoritarian posture of health care providers, the rise of the hospital to a locus of scientific research since the end of the 1800s, the rapid professionalization of some CAM, the interest of some governments in CAM as a solution to the public health care funding crisis, social acknowledgment of cultural, religious and ethnic diversity, a focus on wellness, and above all, the active demands of users, since health care can now be seen as a commodity and consequently consumer preferences and market dynamics dictate the profile of services (Cant \& Sharma, 1999, p. 2; Dinges, 2013, p. 198, 201; Kaptchuk \& Eisenberg, 2001, p. 189, 193; Institute of Medicine, 2005).

However, recent scholarship clearly indicates that pluralism in health care is nothing new: all along history there always were possibilities of choice between different kinds of practitioners and multiple ways of understanding health and sickness (Cant \& Sharma, 1999, p. 1; Dinges, 2013, p. 196). What distinguishes the twentieth century is the attempt by one particular medical culture to claim a monopoly of the global health care marketplace, with the attending right to discredit all other approaches as quackery (Jütte, 2013, p. 8). I am naturally alluding to Western conventional medicine and its strive for hegemony, if not utter dominance, based on the adoption of 'science' as its theory of reference and political, social and legal legitimation (Cant \& Sharman, 1999, p. 6; Dinges, 2013, pp. 198-9).

\footnotetext{
${ }^{24}$ WHO/HIS/CTS 2010/03. Traditional Medicine Health Information Systems. Integrating Traditional Medicine into WHO-FIC, p. 10.
} 
Therefore, following Sarah Cant \& Ursula Sharma (1999, p. 6) more than as a 'rise' of alternative medicine in the past decades, it seems more accurate to describe these developments as a reemergence following a period of 'eclipse.'

One possible reason for the common view is that as an epistemic object, 'medical pluralism' was originally constructed within a context of alterity, i.e. that of the earliest endeavors within Western ethno-medicine and medical anthropology to make sense of non-Western medical cultures (Dinges, 2013, p. 203). Indeed, the term 'medical pluralism' itself -a target of inexhaustible criticism by social historians of medicine and medical anthropologists- ${ }^{25}$ is attributed to Charles Leslie, who minted it in 1973 within the context of his studies of the professionalization of Indian medical systems (Hsu, 2008, p. 317).

Martin Dinges (2013, p. 203) points out that until few years ago, medical pluralism was seen as something "outside of Europe...as a strange phenomenon belonging more to the 'colonies' than to Europe." Cant \& Sharma (1999, p. 3) observe that the reason is that in the "South...the biomedical monopoly of health care is the exception rather than the rule" -the term 'South' being curiously used to designate sub-Saharan Africa and Melanesia... but also Latin America and Asia-.

The emerging picture, however, is quite different. For instance, Ted J. Kaptchuk \& David M. Eisenberg (2001, pp. 189-191) argue that in the United States medicine began in a rich pluralistic environment, remaining as a "shifting collection of coexisting options" until the early decades of the nineteenth century. "This fluid situation," they say, "hardened to sharp antagonism when the medical profession sought to extend its authority, partly as part of the Enlightenment agenda to universalize the benefits of science." As a result, the medical marketplace was a "war zone" all across the nineteenth century. In Europe, observes Robert Jütte $(2013$, p. 8) the health care system was neither homogeneous nor harmonious, but riddled with conflict, while professionalization slowly penetrated it along the $1800 \mathrm{~s}$ as part of the overall modernization of society.

Shortly, the term of Western conventional hegemony seems to have been rather short -to set approximate time coordinates, perhaps from the $1880 \mathrm{~s}$, when the first monolithic national health/insurance systems were created, to the 1960 s or $1980 \mathrm{~s}$, according to the different authors- and all along medical pluralism was a constant element of the history of medicine in Europe and North American (Dinges, 2013, p. 203).

Naturally, nothing of this means to deny that a definite medical system did claim to have the monopoly of the "medical power of interpretation" (Jütte, 2017, p. 1) or that it did not have, and still has, a hegemonic institutional position worldwide. My intention here is to call the attention to the fact that this historical circumstance should no longer hide the fact that T\&CM always was, and is, an integral part of the human experience of health and disease. As Jütte $(2013$, p. 7) suggests, perhaps the debate now rather concerns ethical aspects, like competency, qualifications, behavior, responsibility and personal professional development of practitioners. Or more bluntly, it can be seen as a matter of effectiveness/efficacy: the American Medical Association (AMA) was created in 1847 as a "barricade" between "orthodoxy and irregulars" (Kraptchuk \& Eisenberg, 2002, p. 193). In a famous editorial, AMA journal editors

\footnotetext{
${ }^{25}$ For a discussion of this true 'terminological minefield' (term taken from Kraptchuk \& Eisenberg, 2001, p. 189, who used in a different context) see e.g. Hsu (2008); Ernst (2013).
} 
categorically asserted "There is no alternative medicine. There is only scientifically proven, evidence-based medicine...or unproven medicine" (Fontanarosa \& Lundberg, 1998, p. 1618).

Interestingly, in a recent article Gordon H. Guyatt, the creator of the term 'evidence-based medicine' (EBM) states it has progressed to recognize limitations of evidence alone and has increasingly stressed the need to combine critical appraisal of the evidence with patient's values and preferences through shared decision making" (my emphasis). At the same time Guyatt observes that while pioneers, including Rudolph Virchow, Claude Bernard and Louis Pasteur in Europe and the Flexner report in the United States, cemented scientific inquiry as a bedrock of medicine "EBM does not...offer a new scientific theory of knowledge," but central to its epistemology is the trustworthiness of evidence (Djulbegovic \& Guyatt, 2017, pp. 415416).

From this perspective, the inclusion of TCM in the ICD-11, and of ICTM in the WHO-FIC in the future, can be seen as an acknowledgment of fact, as the unveiling of a state of affairs that not for being invisible was, or is, less real. In this regard, the decisive role of the World Health Organization, as a supranational institution explicitly committed to provide support to the development of a knowledge base and national policies for T\&CM, strengthen its safety, quality and efficacy through regulations and to promote universal health coverage by integrating $\mathrm{T} \& \mathrm{CM}$ and conventional health care into national health systems (WHO, 2013, p. 7) cannot be emphasized enough.

Certainly, the field is still a 'war zone.' But these are times of global overarching transition, and there is no Shakespeare's Edmund to tell us what will follow this eclipse.

\section{Acknowledgments}

I'm most thankful to Prof. Dr. Georges Métailié, who kindly provided me fundamental guidance in the difficult territory of Chinese medicine; to Prof. Dr. Vera Dorofeeva-Lichtmann for her insightful help with Chinese transcriptions; to Prof. Dr. Ana M. Alfonso-Goldfarb and Dr. José Eizayaga for their valuable comments to an early version of this manuscript; and to Institut für Geschichte der Medizin der Robert Bosch Stiftung for their help with sources.

\section{References}

1. Alfonso-Goldfarb, A.M., Waisse, S. \& Ferraz, M. H. (2013). From shelves to cyberspace. Organization of knowledge and the complex identity of history of science. Isis, 104 (3), 551-560. DOI: https://doi.org/10.1086/673274

2. Baer, H. A. (2004). Medical pluralism. In Ember, C. \& Ember, M. (Ed.) Encyclopedia of medical anthropology. Health and illness in the world's cultures. Vol. 1, Topics (pp. 109-116). New York, USA: Kluwer Academic/Plenum Publishers.

3. Bivins, Roberta. (2007). Alternative medicine? A history. Oxford, UK: Oxford University Press. 
4. Bornhöft, G. \& Matthiessen, P. F. (Ed.) (2011). Homeopathy in healthcare. Effectiveness, appropriateness, safety, costs. Berlin, Germany: Springer.

5. Cant, S. \& Sharma, U. (1999). A new medical pluralism? Alternative medicine, doctors, patients and the state. London, England: Routledge.

6. Choi, S.-H., Watanabe, K., Shim, B., Zhu, H. \& Roberts, R. (2006). International Classification of Traditional Medicine: ICTM. Proposal to WHO-FIC Family Development Committee for inclusion of ICTM in the World Organization Family of International Classifications. Meeting of the Collaborating Centres for the Family of International Classifications. Document C408. Available at: https://www.who.int/classifications/network/meetings/en/.

7. Cueto, M. (2004). The ORIGINS of primary health care and SELECTIVE primary health care. American Journal of Public Health, 93 (11), 1864-1874. DOI: https://doi.org/10.2105/ajph.94.11.1864

8. Cueto, M, Brown T.M. \& Fee, E. (2019). The World Health Organization. A history. Cambridge, UK: Cambridge University Press.

9. Dinges, M. (2013). Medical pluralism -past and present. Towards a more precise concept. In Jütte, R. (Ed.). Medical pluralism. Past-present-future (pp. 195-205). Stuttgart, Germany: Franz Steiner.

10. Dinges, M. (2014). Introduction. In Dinges, M. (Ed.) Medical pluralism and homoeopathy in India and Germany (1810-2010). A comparison of practices (pp. 7-30). Stuttgart, Germany: Franz Steiner.

11. Djulbegovic, B. \& Guyatt, G. H. (2017). Progress in evidence-based medicine: a quarter century on. The Lancet, 390, 415-423.

12. Ernst, W. (2013). Medical plurality, medical pluralism and plural medicine. A critical reappraisal of recent scholarship. In Jütte, R. (Ed.). Medical pluralism. Past-present-future (pp. 11-23). Stuttgart, Germany: Franz Steiner.

13. Fontanarosa, P. B. \& Lundberg, G. D. (1998). Alternative medicine meets science. JAMA, 280 (18), 1618-1619. DOI: https://doi.org/10.1001/jama.280.18.1618

14. Foran, B. J. (2007). Medical pluralism and global health policy. The integration of traditional medicine in health care systems. PhD dissertation. PhD in Social Policy. University of Western Sidney, Australia. Available at: https://researchdirect.westernsydney.edu.au/islandora/object/uws:3623

15. Gross, M. (2018). Between party, people and profession. The many faces of the 'doctor' during the Cultural Revolution. Medical History, 62 (3), 333-356. DOI: https://doi.org/10.1017/mdh.2018.23 
16. Hsu, Elisabeth. (2008). Medical pluralism. In Heggenhougen, K. \& Quah, S.R. (Ed.) International encyclopedia of public health (pp. 316-319). Amsterdam, The Netherlands: Elsevier.

17. Institute of Medicine (United States). Committee on the Use of Complementary and Alternative Medicine by the American Public. (2005). Complementary and Alternative Medicine in the United States. Washington D. C.: National Academies Press. Available at: ncbi.nlm.nih.gov/books/NBK83799

18. Jinfgu, T. (1985). Traditional Chinese Medicine. Past, present and future. In Akerelle, O., Stott, G. \& Weibo, L. (Ed.) The role of traditional medicine in primary health care in China (pp. 11-18). Geneva, Switzerland: WHO/Ministry of Public Health of the People's Republic of China. Available at: https://apps.who.int/iris/handle/10665/60624

19. Jütte, R. (Ed.) (2013). Medical pluralism. Past-present-future. Stuttgart, Germany: Franz Steiner.

20. Jütte, R. (2017). Medical pluralism: what can we learn from history?, Inaugural lecture at the Homeopathic World Congress, Leipzig. Available at: http://www.igm-bosch.de/content/language1/downloads/MedicalPluralism.pdf.

21. Kaptchuk, T. J. \& Eisenberg, D. M. (2001). Varieties of healing 1. Medical pluralism in the United States. Annals of Internal Medicine, 2001, 135 (3), 189195.

22. Klayman, D. L. (1985). Qinghaosu (artemisinin). An antimalarial drug from China. Science, 228, 1045-1055.

23. Leslie, C. (1980). Medical pluralism in world perspective [1]. Social Science \& Medicine, 14B, 1919-195.

24. Madden, R., Sykes, C. \& Ustun, T. B. (2007). World Health Organization Family of International Classifications. Definition, scope and purpose. Available at: https://www.who.int/classifications/en/FamilyDocument2007.pdf

25. Métailié, G. (Ed.) (2015). Science and civilization in China, Vol. VI, Part 4. Cambridge, England: Cambridge University Press.

26. Métailié, G. (2019). How traditional Chinese materia medica entered modern medicine, 1956-1977. In Alfonso-Goldfarb, A. M., Ferraz, M. H., Goldfarb, J. L. \& Waisse, S. (Ed.) História da ciência na PUC-SP. Uma viagem de 20 anos (pp. 7682). São Paulo, Brazil: Editora da Pontifícia Universidade Católica de São Paulo.

27. Miller, L. H. \& Su, X. (2011). Artemisinin: a discovery from the Chinese herbal garden. Cell, 146 (6), 855-858. DOI: https://doi.org/10.1016/j.cell.2011.08.024 
28. Morris, W, Gomes, S. \& Allen, M. (2012). International Classification of Traditional Medicine. Global Advances in Health and Medicine 1 (4), 38-41. DOI: https://doi.org/10.7453/gahmj.2012.1.4.005

29. Penkala-Gawęcka, D. \& Rajtar, M. (2016). Introduction to the Special Issue 'Medical Pluralism and Beyond.' Anthropology \& Medicine, 23 (2), 129-134. DOI: https://doi.org/10.1080/13648470.2016.1180584

30. Shi, C.-C., Su, Y.-C., Liao, C.-C. \& Lin, J.-C. (2010). Patterns of medical pluralism among adults. Results from the 2001 National Health Interview Survey in Taiwan. BMC Health Services Research, 10, article number: 191. DOI: https://doi.org/10.1186/1472-6963-10-191

31. Sivin, N. (Ed.) (2001). Science and civilisation in China, Vol. VI, Part 6. Cambridge, England: Cambridge University Press.

32. Souza, E. P. (2010). Ciências de interface: problemas, desafios e estudo de caso. PhD dissertation. PhD in History of Science. Pontifical Catholic University of São Paulo, Brazil. Available at: https://tede2.pucsp.br/bitstream/handle/13239/1/Elaine\%20Pereira\%20de\%20S ouza.pdf

33. Tong, X. (1985). Combining Traditional Chinese Medicine and modern medicine. In Akerelle, O., Stott, G. \& Weibo, L. (Ed.). The role of traditional medicine in primary health care in China (pp. 11-18). Geneva, Switzerland: WHO/Ministry of Public Health of the People's Republic of China. Available at: https://apps.who.int/iris/handle/10665/60624

34. Tu, Y. (2011). The discovery of artemisinin (qinghaosu) and gifts from Chinese medicine. Nature Medicine, 17 (10), 1217-1220. DOI: https://doi.org/10.1038/nm.2471

35. World Health Assembly (WHA) 20. (1967). WHO Nomenclature Regulations 1967. Geneva, Switzerland: World Health Organization. Available at: https://apps.who.int/iris/handle/10665/89478

36. World Health Organization (WHO). (1977). The promotion and development of traditional medicine. Meeting report. Geneva: WHO. Available at: https://apps.who.int/iris/handle/10665/40995

37. World Health Organization (WHO). (1990). A standard international acupuncture nomenclature: memorandum from a WHO meeting. Bulletin of the World Health Organization, 68 (2): 165-169. Available at: https://apps.who.int/iris/handle/10665/50680 
38. World Health Organization (WHO). (2002). WHO Traditional medicine strategy 2002-2005. Geneva, Switzerland: WHO. Available at: https://apps.who.int/iris/bitstream/handle/10665/67163/WHO EDM TRM 2002. 1.pdf? sequence $=1$

39. World Health Organization (WHO). (2013). WHO Traditional medicine strategy 2014-2023. Geneva, Switzerland: WHO. Available at: who.int/medicines/publications/traditional/trm_strategy14_23/en/

40. World Health Organization (WHO). (2019). WHO global report on traditional and complementary medicine 2019. Geneva, Switzerland: WHO. Available at: https://www.who.int/traditional-complementary-integrative-

medicine/WhoGlobalReportOnTraditionalAndComplementaryMedicine2019.pdf ?ua $=1$ 